\title{
Efficacy of Fungicides, Biocontrol Agents and Neem Cake to Suppress the Wilt of Cluster Bean caused by Fusarium solani (Mart.) Sacc
}

\author{
L. Kiran* and R. N. Bunker \\ Department of Plant Pathology, Rajasthan College of Agriculture, Maharana Pratap \\ University of Agriculture and Technology, Udaipur-313001, India \\ *Corresponding author
}

\begin{abstract}
A B S T R A C T
\section{Keywords \\ Cluster bean wilt, Tebuconazole, Trichoderma viride, neem cake} Fusarium solani,

Article Info

Accepted:

12 August 2020

Available Online:

10 September 2020

The present study was carried out with an aim to find out the effective fungicides and biocontrol agents under In vitro and In vivo conditions. In vitro evaluations revealed that Tebuconazole was found highly effective in controlling the mycelial growth of $F$. solani completely at all the concentrations $(50,100,250$ and 500ppm) among the different fungicides tested by poised food technique. The antagonism activity of Trichoderma viride found to be highly effective in controlling the mycelia growth (73.5\%) against $F$. solani among biocontrol agents tested under dual culture method. In vivo study revealed that maximum germination per cent (82.78 per cent) and maximum per cent disease control $(75.66 \%$ at 40days, $85.04 \%$ at 60 days) were recorded in treatment combination of Tebuconazole $(\mathrm{ST})+T$. viride $(\mathrm{SA})+$ neem cake (SA). Thus treatment combination works better in suppressing the wilt disease of cluster bean and also helps in reducing environmental pollution which is caused by over use of chemicals.
\end{abstract}

\section{Introduction}

Cluster bean (Cyamopsis tetragonaloba $\mathrm{L}$.) is an annual legume and the source of guar gum. Traditionally, it is well known as 'Guar' in Rajasthan (Pathak et al, 2010). It is a drought hardy crop of the arid and semi-arid zones and cultivated under rain fed conditions in kharif season. Its seeds contain $18 \%$ protein and $32 \%$ fibre and about $30-33 \%$ gum in the endosperm. The gum is having usages in many industries like cosmetics, pharmaceuticals, textile, mining, oil, drilling, paper, explosive industry etc (Singh, 2014).
Cluster bean is attacked by many diseases which are responsible for its poor quality and low yield resulting in severe economic losses to the country as it is an important cash crop with a great potential for foreign exchange (Chand and Gandhi, 1978). Wilt and root rot caused by Fusarium and Rhizoctonia species are a major problem in cluster bean cultivated under arid zone during rabi season and may cause up to $21.6 \%$ plant loss at pre-emergence and post-emergence stages (Satyavir and Grewal, 1971; Lodha, 1998). Among the diverse pathogens infecting the crop Fusarium solani (Mart.) Sacc. is the major 
fungal pathogen causing significant yield losses. The pathogen causes wilt of seedlings and the diseases plants develops rotting symptom near the soil surface which leads to wilting of host plant (Pareek and Varma, 2014). Wilt of guar was first reported by Singh (1951) from Kanpur. In view of the importance of this disease, there are several workers made attempts In vitro and In vivo using fungicides to combat this pathogen and reduce the losses in yield of the crop (Tetarwal and Trivedi 2011; Kushawah and Rakholiya 2015; Anita and Ratnoo 2015). Since, the pathogen Fusarium solani causing wilt in cluster bean is cosmopolitan in nature and can survive on seed and in soil in the form of its infective propagules that are difficult to control by conventional measures.

The use of IPM strategies for its management is crucial. Looking to the increasing severity of wilt of guar in Rajasthan and keeping in view the importance of the disease, the present studies were undertaken in order to reduce dependence on fungicides alone. Biocontrol (Trichoderma viride) and Organic cakes (Neem cake) were integrated with the fungicide in various combinations for ecofriendly management of this disease.

\section{Materials and Methods}

\section{Isolation, purification and identification of pathogen}

Fungal isolates were isolated from fresh infected root, collar region and stem of cluster bean plant showing typical wilt symptoms which were collected during field survey made around Udaipur district. The diseased wilted parts of stem/roots were cut into smaller bits for isolating the pathogen. These bits were surface sterilized in $0.1 \%$ mercuric chloride $\left(\mathrm{Hgcl}_{2}\right)$ solution for 30 seconds followed by three washing with sterilized distilled water and then transferred into the
Petri plates containing PDA medium and incubated at $28 \pm 1{ }^{\circ} \mathrm{C}$. When the fungal growth occurs from the diseases tissues, it was purified aseptically using hyphal tip method on PDA slants. The pure cultures were preserved for future studies in refrigerator at $4^{\circ} \mathrm{C}$. The pathogen isolates were mainly identified on the basis of cultural and morphological characters as Fusarium solani (Mart.) Sacc. as described by Burnett and Hunter, 2003; Leslie and Summerell, 2006. Among the isolates obtained, highly virulent fungal isolate $F$. solani(BKU Fs-03) was chosen for further management studies based up on their pathogenic virulence caused on the cluster bean cultivars (Pusa Navbahar and Swati) tested under sick soil method.

\section{In vitro efficacy of fungicides}

Efficacy of six fungicides (three non-systemic and three systemic) viz, Mancozeb 75 WP (Stargem-45), Carbendazim 12\% WP + Mancozeb 63\% WP (Saaf), Copper oxychloride $50 \mathrm{WP}$ (Maincop), Tebuconazole 25 EC (Folicur), Propiconazole 25 EC (Tilt), and Hexaconazole 5 SC (Mainex) against mycelial growth of $F$. solani was tested by poisoned food technique (Sinclair and Dhingra, 1985). Four different concentrations viz., 50, 100, 250 and 500 ppm of each fungicide was tested. The required quantity of each chemical at different concentration was added aseptically in $100 \mathrm{ml}$ PDA in $250 \mathrm{ml}$ flasks and shaken well for mixing of the chemical.

After that, pouring of medium was done and allowed to solidify. $5 \mathrm{~mm}$ diameter mycelial disc, cut from the periphery of 10 days old fungus cultures were inoculated into each Petri plates and incubated at $28 \pm 1^{\circ} \mathrm{C}$ for $7-8$ days. In each treatment, five replications were maintained. Observations on linear growth were recorded when full growth of fungus observed in control Petri plate and per cent 
growth inhibition was calculated by following formula (Vincent's, 1947);

Per cent growth inhibition $=\frac{\text { C }}{\text { C }-\mathrm{T}} \times 100$ where,

$\mathrm{C}=$ Growth of the colony in control $(\mathrm{mm})$

$\mathrm{T}=$ Growth of colony in respective treatment (mm)

\section{In vitro efficacy of bioagents}

In vitro efficacy of four bio-control agents two fungal [viz; Trichoderma viride (IIHRTv-5) and T. harzianum (Jh.h.89-2)] and two bacterial (viz; Pseudomonas fluorescens and Bacillus subtilis) were tested by using dual culture plate method on PDA medium (Bell et al., 1982). $20 \mathrm{ml}$ PDA media was poured aseptically in each Petri plates and allowed to solidify. Then, Petri plates were inoculated with $5 \mathrm{~mm}$ mycelia disc of 7 days old culture of $F$. solani and fungal bioagents using sterilized cork borer by placing on solid media approximately $4 \mathrm{~cm}$ away from each other. In case of bacterial bioagents evaluation, $5 \mathrm{~mm}$ fungal mycelia disc was placed at the centre of each plates and bacterial bioagent of 2-3 day old culture was streaked around the fungal disc at 4 sides. Control plates were also maintained in bioagent free conditions and incubated at $28 \pm 1^{\circ} \mathrm{C}$ for 7 days. In each treatment five replications were maintained. Growth of test pathogen in dual culture and in control plates were recorded and Per cent growth inhibition zone of pathogen and Index of antagonism were determined in each treatment by following standard formula,

$$
\mathrm{I}=\frac{\mathrm{C}-\mathrm{T}}{\mathrm{C}} \times 100
$$

Where,

$I=$ Per cent growth inhibition of pathogen
$\mathrm{C}=$ Growth of test fungus in control (mm)

$\mathrm{T}=$ Growth of test fungus in respective treatment $(\mathrm{mm})$.

Integrated management of cluster bean wilt caused by Fusarium solani under field conditions

Based up on the In vitro studies, one fungicide Tebuconazole $25 \mathrm{EC}$, two bioagents Trichoderma viride and Pseudomonas fluorescens that were found most effective was further evaluated in field condition alone as well as their integration with the neem cake for the management of cluster bean wilt. The pathogen $F$. solani isolate (BKU Fs-03) was mass multiplied using sterilized sorghum grain substrate under laboratory conditions and mixed with field soil in micro plots @ 10 $\mathrm{g} /$ plot before sowing. Required quantity of Tebuconazole 25 EC $(0.1 \%)$, T. viride $(2 \%)$, $P$. Fluorescens (2\%) and neem cake $(300 \mathrm{gm} / \mathrm{plot}$ in individual or $100 \mathrm{gm} / \mathrm{plot}$ in combination) were used alone or in combination of each were treated at the time of seed sowing. Cluster bean cultivar 'Pusa Navbahar' was raised in a randomized block design with three replications and eight treatments were imposed as in the table 3. Observations on the number of total germinated seedlings were recorded at 10 days and number of infected plants showing typical wilting symptoms were taken along with control at 40 and 60days. The per cent wilt incidence and Per cent wilt control were calculated to find out the best treatment for the management of cluster bean wilt by using standard formula given by Wheeler (1969);

Per cent seed germination $=\frac{\text { Number of seeds germinated } / \text { plot }}{\text { Total number of seeds sowed } / \text { plot }} \times 100$

Per cent wilt incidence $=\frac{\text { Number of wilt infected plants per }}{\text { Total number of plants per plot }} \times 100$ 
Per cent wilt control $=\frac{\text { PWI }_{(\mathrm{C})}-\mathrm{PWI}_{(\mathrm{T})}}{\mathrm{PWI}_{(\mathrm{C})}} \times 100$

Where, PWI ${ }_{(\mathrm{C})}-$ Per cent wilt incidence in control plot

PWI ${ }_{(\mathrm{T})}-$ Per cent wilt incidence in treated plot

\section{Results and Discussion}

In vitro testing of fungicides against $F$. solani (BKU Fs-03)

All the tested fungicides significantly $(\mathrm{P}=0.05)$ inhibited the mycelial growth of $F$. solani at all concentrations In vitro (Table-1). Tebuconazole was found most effective with 94.44 per cent inhibition of the mycelial growth of $F$. solani at all concentrations (50, 100, 250 and $500 \mathrm{ppm}$ ) followed by Propiconazole was found effective with inhibition of $66.44,74.0,85.78$ and $94.44 \%$ at 50, 100, 250 and 500 ppm, respectively.

Hexaconazole, Saaf and Mancozeb showed $90.22 \%, 84.89 \%$ and $40.67 \%$ inhibition at 500 ppm, respectively. Copper oxychloride was found least effective at all concentrations against $F$. solani.

Similar results have been observed by Timbadiya (2013) reported that Tebuconazole showed complete inhibition (100\%) followed by Propiconazole $(92.35 \%)$ against Fusarium solani causing wilt in cluster bean under In vitro. Kushawah and Rakholiya (2015) reported that Propiconazole and Hexaconazole were found relatively effective against $F$. solani with 91.67 and 77.44 per cent growth inhibition at 250 ppm concentration.

In vitro testing of biocontrol agents against $F$. solani isolate (BKU Fs-03)

All the four bioagents were significantly $(P=0.05)$ showed the antagonism and check / inhibited the mycelial growth of $F$. solani isolate (BKU Fs-03) from Table-2. Severe antagonism and significant higher percent inhibition of $F$. solani growth $(73.5 \%)$ was recorded by $T$. viride which was followed by T. harzianum and Pseudomonas fluorescens showed moderate antagonism with $64.0 \%$ and $59.3 \%$ growth inhibition, respectively.

The least and weak antagonism was showed by Bacillus subtilis. Sneha (2016) reported that maximum inhibition of Fusarium solani (83.88\%) was recorded with the bioagent $T$. viride followed by that of $P$. fluorescens and B. subtilis. The reports of Kapoor et al, 2010; Singh et al, 2010; Ram and Pandey, 2011 were depicted the similar results.

Integrated management of cluster bean wilt caused by $F$. solani under field conditions

The data presented in table 3 showed that all the treatments are significantly effective over control. Maximum seed germination $(82.78 \%)$, minimum per cent wilt incidence $(12.92 \%)$ with highest wilt control $75.66 \%$, $85.04 \%$ recorded at 40 and 60 days, respectively in the treatment combination of Tebuconazole $(\mathrm{ST})+T$. viride $(\mathrm{SA})+$ neem cake (SA) that was found most effective followed by Tebuconazole $(\mathrm{ST})+T$. viride (SA) had $77.22 \%$ germination, $17.39 \%$ wilt incidence with $79.88 \%$ wilt control at 60days after sowing.

The treatment combination Tebuconazole $(\mathrm{ST})+$ neem cake (SA) showed $69.70 \%$ wilt control at 60 days, while $P$. fluorescens (ST) + (neem cake $+T$. viride) (SA) recorded $61.43 \%$ wilt control at 60 days.

Among the individual treatments, Tebuconazole (ST) showed $56.67 \%$ germination with $51.21 \%$ wilt control at 60days while $T$. viride (SA) recorded $51.67 \%$ germination with 36.11 wilt control at 60days. 
Table.1 Comparative efficacy of different fungicides on the growth of Fusarium solani isolate (BKU Fs-03) in vitro

\begin{tabular}{|c|c|c|c|c|c|c|c|c|c|}
\hline \multirow[t]{3}{*}{ Treaments } & \multirow[t]{3}{*}{ Name of the Fungicide } & \multicolumn{8}{|c|}{ Different concentrations (ppm) } \\
\hline & & \multicolumn{2}{|c|}{50} & \multicolumn{2}{|c|}{100} & \multicolumn{2}{|c|}{250} & \multicolumn{2}{|c|}{500} \\
\hline & & $\begin{array}{c}\text { Colony } \\
\text { Diameter } \\
(\mathrm{mm})^{*}\end{array}$ & $\begin{array}{c}\text { Per Cent } \\
\text { Growth } \\
\text { inhibition* }\end{array}$ & $\begin{array}{l}\text { Colony } \\
\text { Diameter } \\
(\mathrm{mm})^{*}\end{array}$ & $\begin{array}{l}\text { Per Cent } \\
\text { Growth } \\
\text { inhibition* }\end{array}$ & $\begin{array}{l}\text { Colony } \\
\text { Diameter } \\
(\mathrm{mm})^{*}\end{array}$ & $\begin{array}{c}\text { Per Cent } \\
\text { Growth } \\
\text { inhibition* }\end{array}$ & $\begin{array}{l}\text { Colony } \\
\text { Diameter } \\
(\mathrm{mm})^{*}\end{array}$ & $\begin{array}{l}\text { Per Cent } \\
\text { Growth } \\
\text { inhibition* }\end{array}$ \\
\hline $\mathbf{T}_{1}$ & Mancozeb 75 WP & $\begin{array}{c}80.40 \\
(63.74)\end{array}$ & $\begin{array}{c}10.67 \\
(18.91)\end{array}$ & $\begin{array}{c}71.00 \\
(57.41)\end{array}$ & $\begin{array}{c}20.44 \\
(26.85)\end{array}$ & $\begin{array}{c}62.20 \\
(52.04)\end{array}$ & $\begin{array}{c}30.89 \\
(33.74)\end{array}$ & $\begin{array}{c}53.40 \\
(46.93)\end{array}$ & $\begin{array}{c}40.67 \\
(39.60)\end{array}$ \\
\hline $\mathbf{T}_{2}$ & Saaf 75WP & $\begin{array}{c}45.40 \\
(42.34)\end{array}$ & $\begin{array}{c}48.89 \\
(44.35) \\
\end{array}$ & $\begin{array}{c}36.20 \\
(36.97) \\
\end{array}$ & $\begin{array}{c}59.78 \\
(50.62) \\
\end{array}$ & $\begin{array}{c}23.4 \\
(28.90) \\
\end{array}$ & $\begin{array}{c}74.00 \\
(59.33) \\
\end{array}$ & $\begin{array}{c}13.80 \\
(21.78) \\
\end{array}$ & $\begin{array}{c}84.89 \\
(67.11) \\
\end{array}$ \\
\hline $\mathbf{T}_{3}$ & Copper oxychloride $50 \mathrm{WP}$ & $\begin{array}{c}84.80 \\
(67.06)\end{array}$ & $\begin{array}{c}5.78 \\
(13.72)\end{array}$ & $\begin{array}{c}78.00 \\
(62.01)\end{array}$ & $\begin{array}{c}12.89 \\
(20.99)\end{array}$ & $\begin{array}{c}70.40 \\
(57.03)\end{array}$ & $\begin{array}{c}21.78 \\
(27.78)\end{array}$ & $\begin{array}{c}60.40 \\
(50.99)\end{array}$ & $\begin{array}{c}32.89 \\
(34.97)\end{array}$ \\
\hline $\mathbf{T}_{4}$ & Tebuconazole 25 EC & $\begin{array}{c}5.00 \\
(12.92) \\
\end{array}$ & $\begin{array}{c}94.44 \\
(76.33)\end{array}$ & $\begin{array}{c}5.00 \\
(12.92) \\
\end{array}$ & $\begin{array}{c}94.44 \\
(76.33)\end{array}$ & $\begin{array}{c}5.00 \\
(12.92)\end{array}$ & $\begin{array}{c}94.44 \\
(76.33)\end{array}$ & $\begin{array}{c}5.00 \\
(12.92) \\
\end{array}$ & $\begin{array}{c}94.44 \\
(76.33)\end{array}$ \\
\hline $\mathbf{T}_{5}$ & Propiconazole 25 EC & $\begin{array}{c}30.20 \\
(33.31)\end{array}$ & $\begin{array}{c}66.44 \\
(54.58)\end{array}$ & $\begin{array}{c}23.40 \\
(28.91)\end{array}$ & $\begin{array}{c}74.00 \\
(59.33)\end{array}$ & $\begin{array}{c}12.80 \\
(20.95)\end{array}$ & $\begin{array}{c}85.78 \\
(67.83)\end{array}$ & $\begin{array}{c}5.00 \\
(12.92)\end{array}$ & $\begin{array}{c}94.44 \\
(76.33)\end{array}$ \\
\hline $\mathbf{T}_{6}$ & Hexaconazole $5 \mathrm{SC}$ & $\begin{array}{c}47.60 \\
(43.61)\end{array}$ & $\begin{array}{c}47.11 \\
(43.32)\end{array}$ & $\begin{array}{c}34.80 \\
(36.13)\end{array}$ & $\begin{array}{c}61.56 \\
(51.66)\end{array}$ & $\begin{array}{c}19.60 \\
(26.26)\end{array}$ & $\begin{array}{c}78.22 \\
(62.17)\end{array}$ & $\begin{array}{c}8.80 \\
(17.23)\end{array}$ & $\begin{array}{c}90.22 \\
(71.76)\end{array}$ \\
\hline $\mathbf{T}_{7}$ & Control & $\begin{array}{c}90.00 \\
(71.54)\end{array}$ & 0.00 & $\begin{array}{c}90.00 \\
(71.54)\end{array}$ & 0.00 & $\begin{array}{c}90.00 \\
(71.54)\end{array}$ & 0.00 & $\begin{array}{c}90.00 \\
(71.54)\end{array}$ & 0.00 \\
\hline SEm \pm & & 0.546 & 0.768 & 0.393 & 0.445 & 0.391 & 0.445 & 0.365 & 0.396 \\
\hline $\mathbf{C D}(\mathbf{P}$ & $0.05)$ & 1.590 & 2.235 & 1.145 & 1.295 & 1.137 & 1.296 & 1.062 & 1.153 \\
\hline
\end{tabular}

* Mean of five replications; Figures in parentheses are arcsine $\sqrt{ }$ per cent angular transformed values. 
Table.2 Per cent growth inhibition of Fusarium solani (BKU Fs-03) isolate by different bioagents in vitro

\begin{tabular}{|c|c|c|c|c|}
\hline Treatments & Bio-control agent and procured places & Mycelial growth $(\mathrm{mm}) *$ & Per Cent growth Inhibition * & Antagonism Index*** \\
\hline $\mathbf{T}_{1}$ & T. viride (IIHR-TV-5) & $\begin{array}{c}23.8 \\
(29.2)\end{array}$ & $\begin{array}{c}73.5 \\
(59.1)\end{array}$ & ++++ \\
\hline $\mathbf{T}_{2}$ & T. harzianum (Jh.h.89-2) & $\begin{array}{c}32.4 \\
(34.7)\end{array}$ & $\begin{array}{c}64.0 \\
(53.1)\end{array}$ & +++ \\
\hline $\mathbf{T}_{\mathbf{3}}$ & Pseudomonas fluorescens & $\begin{array}{c}36.6 \\
(37.2)\end{array}$ & $\begin{array}{c}59.3 \\
(50.4)\end{array}$ & +++ \\
\hline $\mathbf{T}_{4}$ & Bacillus subtilis & $\begin{array}{c}53.8 \\
(47.2)\end{array}$ & $\begin{array}{c}40.2 \\
(39.3)\end{array}$ & ++ \\
\hline $\mathbf{T}_{5}$ & Control & $\begin{array}{c}90.0 \\
(71.6)\end{array}$ & 0.00 & -- \\
\hline \multicolumn{2}{|l|}{ SEm \pm} & 0.576 & \multicolumn{2}{|l|}{0.628} \\
\hline \multicolumn{2}{|l|}{$\mathrm{CD}(\mathrm{P}=\mathbf{0 . 0 5})$} & 1.710 & \multicolumn{2}{|l|}{1.865} \\
\hline
\end{tabular}

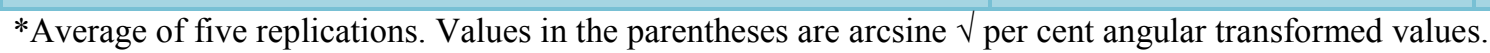

** Antagonism index (Bell et al., 1982)

$++++=$ Severe antagonism

$+++=$ Moderate antagonism

$++=$ Weak antagonism

$--\quad=$ No antagonism 
Table.3 Relative efficacy of promising fungicide, bioagent and neem cake for the management in wilt disease of cluster bean cultivar 'Pusa Navbahar"' in micro plots

\begin{tabular}{|c|c|c|c|c|c|c|}
\hline \multirow[t]{2}{*}{ S.No. } & \multirow[t]{2}{*}{ Treatments } & \multirow{2}{*}{$\begin{array}{l}\text { Germination } \\
\text { per cent }\end{array}$} & \multicolumn{2}{|c|}{ Per cent wilt incidence* } & \multicolumn{2}{|c|}{ Per cent wilt control* } \\
\hline & & & Up to 40days & Up to 60days & Up to 40days & Up to 60 days \\
\hline 01. & Tebuconazole 25 EC @ 0.1\% (ST) & $\begin{array}{c}56.67 \\
(48.83)\end{array}$ & $\begin{array}{l}32.35 \\
(34.48)\end{array}$ & $\begin{array}{l}42.16 \\
(40.44)\end{array}$ & 39.05 & 51.21 \\
\hline 2. & Trichodermaviride @ (2\%) (SA) & $\begin{array}{c}51.67 \\
(45.94)\end{array}$ & $\begin{array}{l}43.75 \\
(41.31)\end{array}$ & $\begin{array}{c}55.21 \\
(47.99)\end{array}$ & 17.57 & 36.11 \\
\hline 3. & Neem cake (SA) @ 300gm /sqm. & $\begin{array}{l}54.44 \\
(47.54)\end{array}$ & $\begin{array}{c}44.08 \\
(41.51)\end{array}$ & $\begin{array}{c}60.22 \\
(50.89)\end{array}$ & 16.95 & 30.32 \\
\hline 4. & $\begin{array}{l}\text { Tebuconazole 25 EC @ } 0.1 \%(\mathrm{ST})+ \\
\text { Trichodermaviride @ (2\%)(SA) }\end{array}$ & $\begin{array}{c}77.22 \\
(61.51)\end{array}$ & $\begin{array}{c}15.94 \\
(23.45)\end{array}$ & $\begin{array}{c}17.39 \\
(24.61)\end{array}$ & 69.96 & 79.88 \\
\hline 5. & $\begin{array}{l}\text { Tebuconazole } 25 \text { EC @ 0.1\% (ST) + Neem } \\
\text { cake (SA) }\end{array}$ & $\begin{array}{l}70.56 \\
(57.19)\end{array}$ & $\begin{array}{l}23.81 \\
(29.17)\end{array}$ & $\begin{array}{c}26.19 \\
(30.75)\end{array}$ & 55.14 & 69.70 \\
\hline 6. & $\begin{array}{l}\text { Tebuconazole 25 EC @ } 0.1 \% \text { (ST) + } \\
\text { Neemcake (SA) + Trichoderma viride @ } \\
(2 \%)(\mathrm{SA})\end{array}$ & $\begin{array}{c}82.78 \\
(65.65)\end{array}$ & $\begin{array}{c}12.92 \\
(20.81)\end{array}$ & $\begin{array}{c}12.92 \\
(20.81)\end{array}$ & 75.66 & 85.04 \\
\hline 7. & $\begin{array}{l}\text { Pseudomonas fluorescens@ }(2 \%)(\mathrm{ST})+ \\
\text { Neem cake (SA)+Trichoderma viride@ } \\
(2 \%)(\mathrm{SA})\end{array}$ & $\begin{array}{c}70.56 \\
(57.19)\end{array}$ & $\begin{array}{c}22.52 \\
(28.28)\end{array}$ & $\begin{array}{c}33.33 \\
(35.23)\end{array}$ & 57.57 & 61.43 \\
\hline \multirow[t]{3}{*}{8.} & Control & $\begin{array}{c}45.00 \\
(42.09)\end{array}$ & $\begin{array}{c}53.08 \\
(46.80)\end{array}$ & $\begin{array}{c}86.42 \\
(72.11)\end{array}$ & 0.00 & 0.00 \\
\hline & SEm \pm & 1.900 & 2.716 & 3.60 & -- & -- \\
\hline & $\mathrm{CD}(P=0.05)$ & 5.820 & 8.317 & 11.04 & -- & -- \\
\hline
\end{tabular}

*Mean of three replications; Figures in parentheses are arcsine $\sqrt{ }$ per cent angular transformed values.

ST- Seed treatment and SA- Soil application 


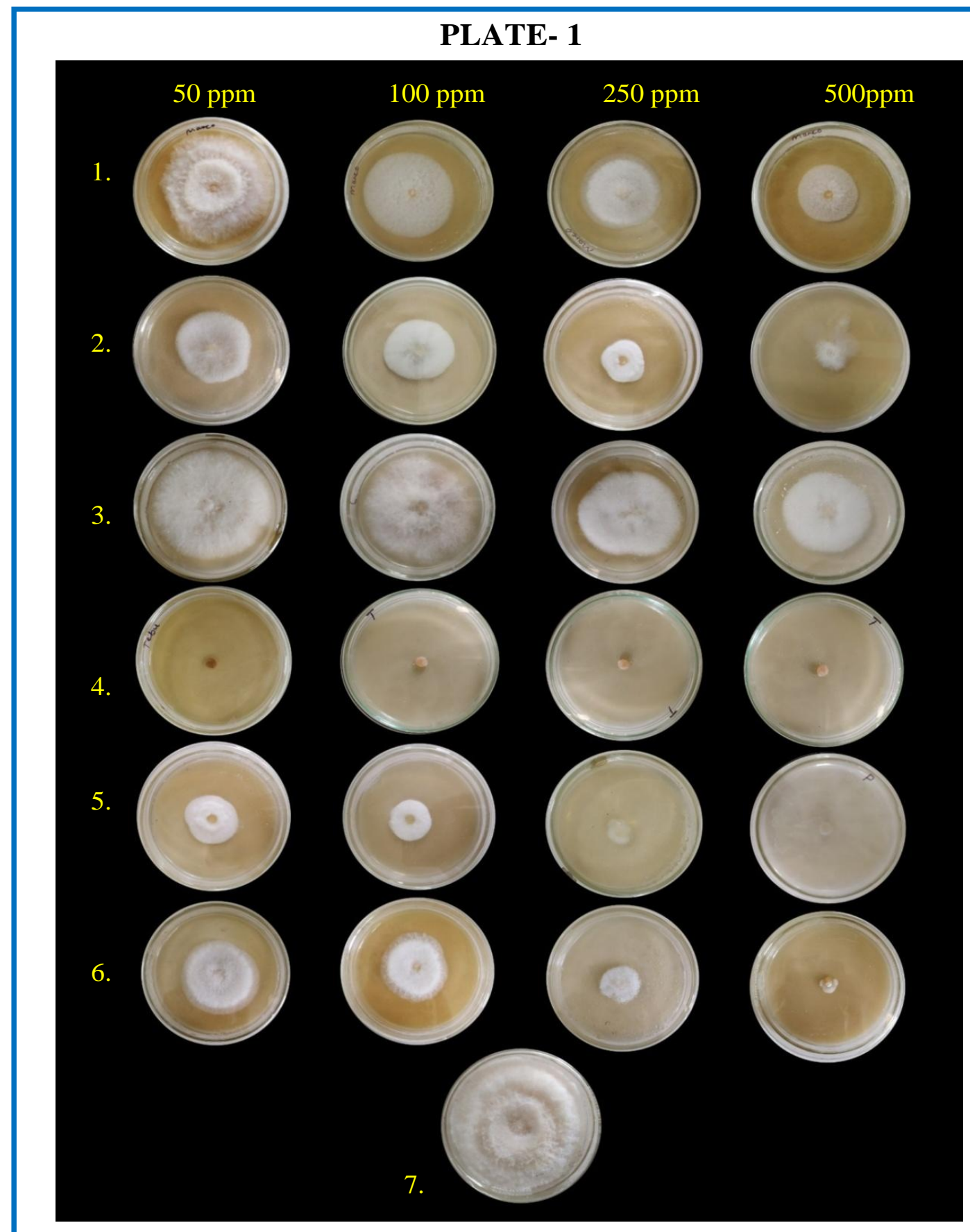

Fig. 1-7: Inhibition of mycelia growth of Fusarium solani (BKU Fs-03) at different concentrations of various fungicides in vitro.

Fig: 1. Mancozeb 75 WP Fig: 2. Saaf 75 WP Fig: 3. Copper oxychloride 50 WP Fig: 4. Tebuconazole 25 EC Fig:5. Propiconazole 25 EC Fig: 6. Hexaconazole 5 SC Fig:7. Control 


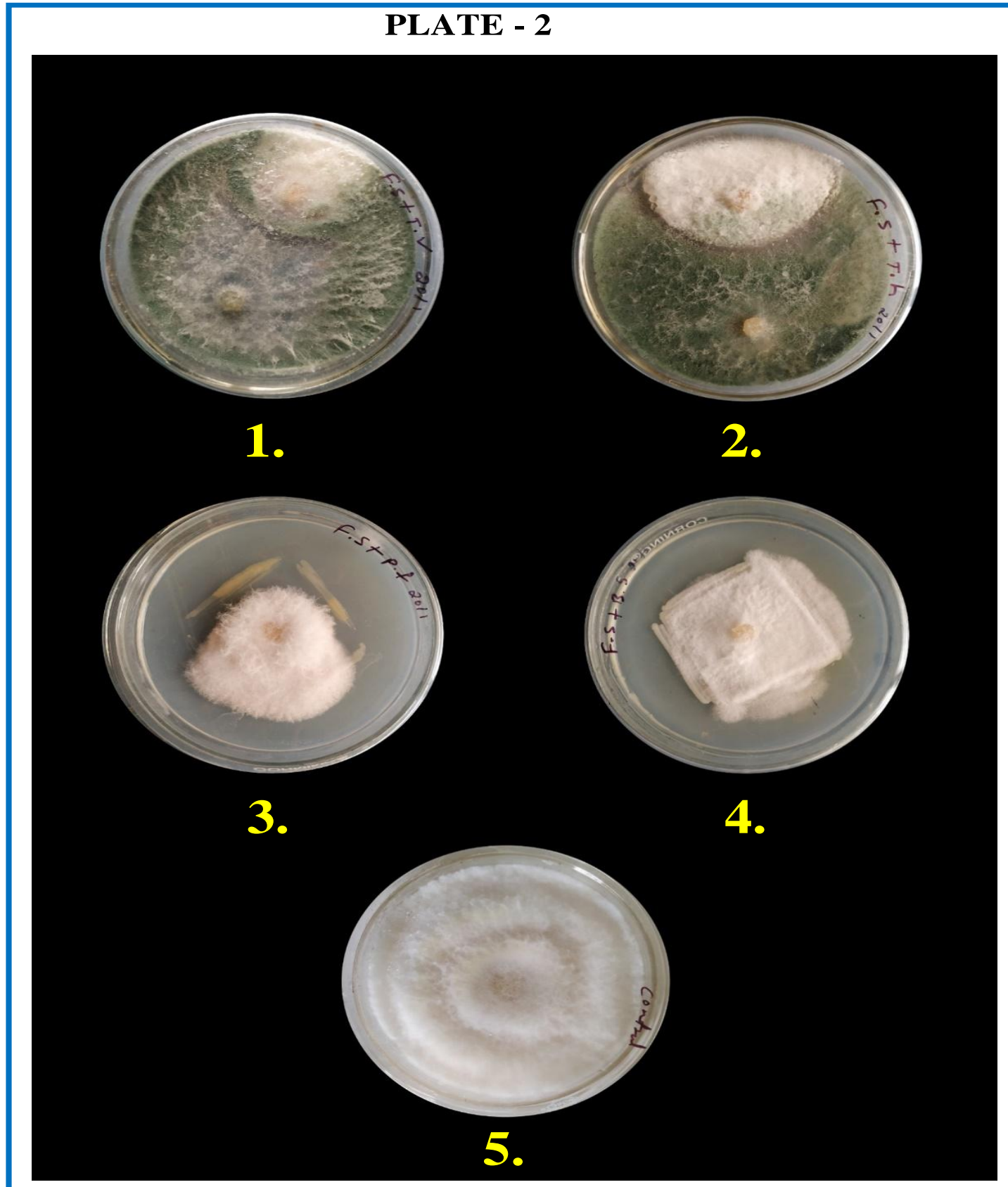

Fig. 1-5: Efficacy of different bioagents aganist Fusarium solani (BKU Fs-03) isolate in vitro.

\section{Trichoderma. viride 2. Trichoderma harzianum}

3. Pseudomonas fluorescens 4. Bacillus subtilis 5. Control 


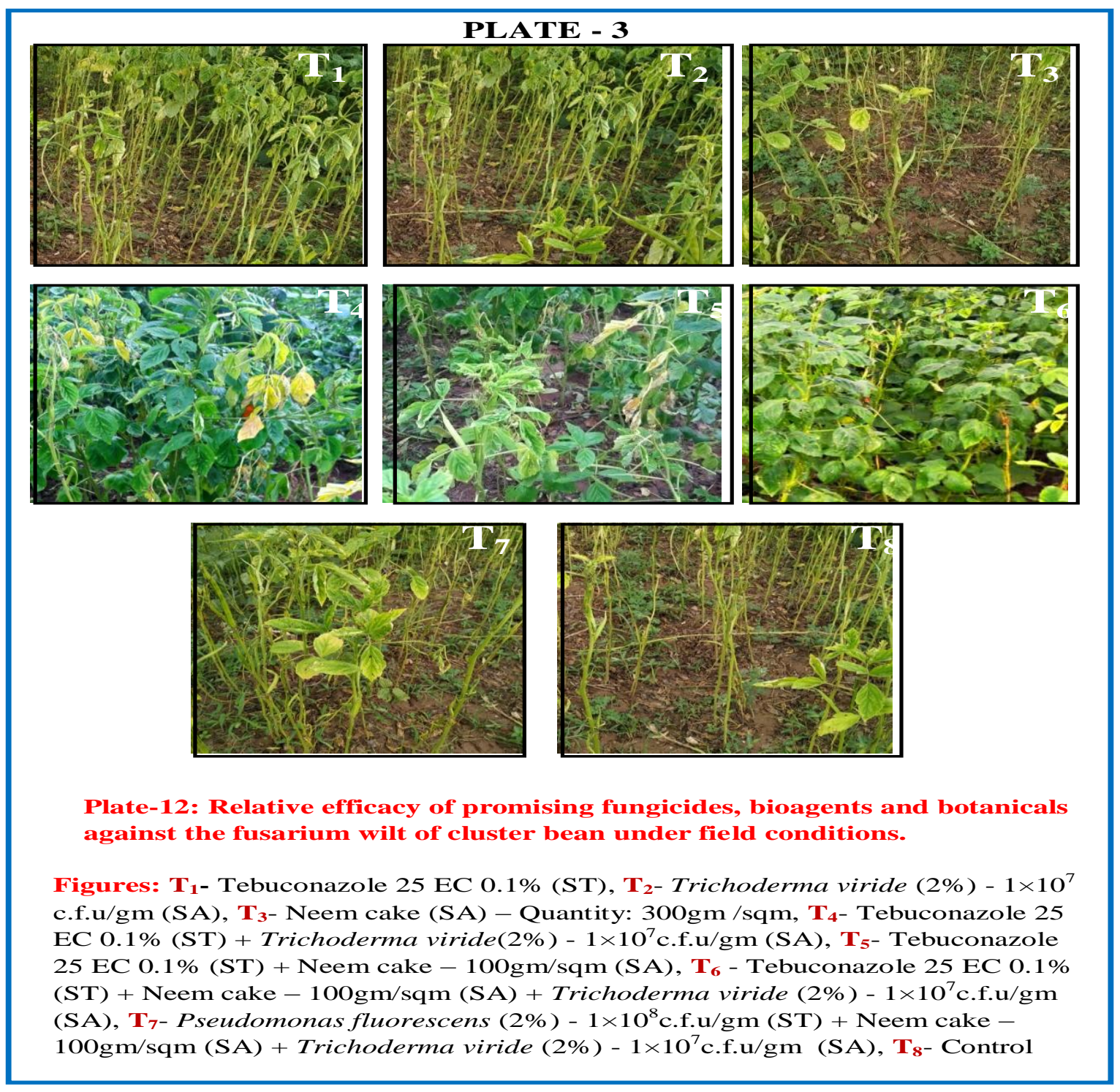

The treatment neem application showed lowest per cent wilt control $(30.32 \%$ at 60days) as compare to control. Anita and Ratnoo (2015) reported that most effective treatment was with Bavistin (ST) + Neem oil $+T$. harzianum + neem cake (SA) to control the root rot of pea caused by $F$. solani. Kumar and Girija (2003) showed that the combined treatment of $T$. viride $(\mathrm{ST}+\mathrm{SA})+$ neem cake $150 \mathrm{~kg} / \mathrm{ha}(\mathrm{SA})+$ soil drenching of Mancozeb $0.3 \%$ significantly controlled the Fusarium wilt of cowpea with $16.66 \%$ least disease index and it increased the biomass, pod yield of the crop. Therefore, integrated management strategy would help to work out the plans to reduce indiscriminate use of fungicides, to minimize the chance of development of resistance against fungicides and to suppress the growth of seed and soil borne pathogens at maximum level.

\section{Acknowledgement}

The authors would like to thank Department of Plant Pathology, Rajasthan college of Agriculture, MPUAT, Udaipur, Rajasthan, India for providing all kinds of required facilities to carry out the present study. 


\section{References}

Anita, S. and Ratnoo, S.R. 2015. Integrated management of root rot of pea (Pisum sativum L.) caused by Fusarium solani (Mart). Department of Plant Pathology, MPUAT, Udaipur. Ph.D. Thesis. Pp 135.

Bell, D. K., Wells, H.D. and Markham, C.R. 1982. In vitro antagonism of Trichoderma spp. against six fungal pathogens. Phytopathology, 72: 379382.

Burnett, H.L. and Hunter, B.B. 2003. Illustrated genera of imperfect fungi. 4th ed. Burgess Publishing Co. Minneapolis, Minnesota, USA.

Chand, J.N. and Gandhi, S.K. 1978. Diseases of guar and their control. Forage Research, 4(A): 49-66.

Kapoor, S., Jaiswal, A., and Shukla, D.N. 2010. Eco- friendly strategies for management of Fusarium wilt of Pisum sativum L. African Journal of Microbiology Research, 6(48): 73977400.

Kumar, S. and Girija, V.K. 2003. Integrated management of fusarium wilt of vegetable cowpea (Vigna unguiculata sub sp. Sesquipedalis (L.) Verdcourt). Department of Plant Pathology, College of Agriculture, Vellayani. M.Sc. (Agri.) Thesis Pp 115.

Kushawah, P.S. and Rakholiya, K.B. 2015. Symptomatology and management of Fusarium wilt of cluster bean (Cyamopsis tetragonaloba L.). Department of Plant Pathology, Navsari agricultural university, Navsari. M.Sc. (Agri.) Thesis. Pp 93.

Leslie, J.F. and Summerell, B.A. 2006. The Fusarium laboratory manual. $1^{\text {st }}$ Ed. Blackwell publishing limited, Oxford, London.

Lodha, S. 1998. Effect of sources of inoculum on population dynamics of
Macrophomina phaseolina and disease intensity in cluster bean. Indian Phytopathology, 51(2):175-179.

Pareek, V. and Varma, R. 2014. Phyto pathological effects and disease transmission in cluster bean seeds grown in Rajasthan. Indian Journal of Plant Science, 3 (2): 26-30.

Pathak, R., Singh, S.K., Singh, M. and Henry, A. 2010. Molecular assessment of genetic diversity in cluster bean (Cyamopsis tetragonoloba). Journal of Genetics, 89(2): 243-246.

Ram, H. and Pandey, R.N. 2011. Efficacy of bio-control agents and fungicides in the management of wilt of pigeon pea. Indian Phytopathology, 64(3): 269-271.

Sinclair, J. B. and Dhingara, O. D. 1985. "Basic Plant Pathology methods." Publ. by CRC Press. Inc. Corporate Buld, M.W. Boca Raton, Florida. Pp. 285315.

Singh, P, K., Khan, A., Gogoi, R. and Jaiswal, R.K. 2010. Plant leaf extracts and bioagents for eco-friendly management of wilt of pigeon pea caused by Fusarium udum. Indian Phytopathology, 63 (3): 343-344.

Singh, R. 2014. Improved cultivation practices for cluster bean in kharif and summer season (PDF), Publications, Central Arid Zone Research Institute, Jodhpur, Rajasthan.

Singh, R. S. 1951. Root rot of guar. Science and culture, 17:131-34.

Sneha, S.G. 2016. Investigation and management of root rot in cluster bean. (Plant pathology), Dr.Panjabrao Deshmukh Krishi Vidyapeeth, Akola, Maharashtra. M. Sc. (Agri.) Thesis Pp 50.

Tetarwal, J.P. and Trivedi, A. 2011. Integrated management of root-rot of soybean (Glycine max L.). Department of Plant Pathology, MPUAT, Udaipur. M.Sc. (Agri.) Thesis Pp 68. 
Timbadiya, A.D. 2013. Management of root rot [Fusarium solani (Mart.) Sacc.] of cluster bean. Department of plant pathology, Junagadh agricultural university, Junagadh. M.Sc. (Agri.) Thesis. Pp 111.

Vincent, J.M. 1947. Distortion of fungal hyphae in the presence of certain inhibitors. Nature, 15: 850.

Satyavir, S. and Grewal, J.S. 1971. Evaluation of fungicides against Fusarium caeruleum causal organism of guar wilt. Indian Phytopathology, 25:65-68.

Wheeler, B.E.J. 1969. An introduction to plant disease. John wiley and sons Ltd., London.

\section{How to cite this article:}

Kiran, L. and Bunker, R. N. 2020. Efficacy of Fungicides, Biocontrol Agents and Neem Cake to Suppress the Wilt of Cluster Bean caused by Fusarium solani (Mart.) Sacc. Int.J.Curr.Microbiol.App.Sci. 9(09): 1339-1350. doi: https://doi.org/10.20546/ijcmas.2020.909.170 